\title{
COVID-19 TRIAGE AMONG HOSPITALIZED NEONATES IN TUZLA CANTON
}

\author{
Devleta Hadzic, ${ }^{1}$ Fahrija Skokic, ${ }^{1}$ Selmira Brkic ${ }^{2}$ \\ ${ }^{1}$ Pediatric Clinic, University Clinical Center of Tuzla, Bosnia and Herzegovina \\ ${ }^{2}$ Faculty of Medicine University of Tuzla, Bosnia and Herzegovina
}

Primljen/Received 16. 03. 2021. god.

Abstract: Aim: To evaluate the incidence, characteristics, transmission, and outcomes of COVID-19 infection in hospitalized neonates in Tuzla Canton and to emphasize the importance of quality triage in the prevention and control of infection.

Material and Methods: A retrospective cohort study, which included all consecutive neonates suspected of COVID-19 infection, and which required screening supervision in the triage department, from those who required hospital treatment at the Pediatric Clinic, University Clinical Center Tuzla for 12 months. (January 1 to December 31, 2020). Statistical analysis applied standard methods, and the research was approved by the Ethics Committee of the institution.

Results: In the observed period, in the neonatal triage department, 111 neonates suspected to COVID-19 were treated, with no gender difference. Among them were 92 neonates of mothers suspected of COVID-19 (66 admitted immediately after birth, 26 readmitted after discharge home), and 19 neonates of mothers positive for COVID-19 (16 admitted immediately after birth, 3 readmitted). Cesarean delivery was a more common delivery option, and fever a more common symptom in COVID-19 positive mothers, but without statistical significance. The neonates from COVID-19 suspected mothers formed a heterogeneous group, with common perinatal problems, while neonates from COVID-19 positive mothers, hospitalized immediately after birth, were almost term neonates with appropriate birth weight, without need for a lot of treatment. All neonates hospitalized immediately after birth were negative for COVID-19. The only three COVID-19 positive neonates were readmitted after previous discharge home, and they had mild symptoms, mostly one-day fever, and they all recovered completely. All of these neonates are under further follow-up after discharge from the hospital,
Prihvaćen/Accepted 16. 04. 2021. god.

and all are, for now, in good general condition, and all have continued to breastfeed.

Conclusion: Neonates born to mothers with positive COVID-19 infection generally have favorable outcomes, with no convincing case of vertical transmission. Neonatal COVID-19 is mostly asymptomatic, acquired postnatally, and associated with favorable outcomes. The importance of quality triage in the prevention and control of infection is crucial, with consistent implementation of safe practices including proper patient isolation and appropriate protective equipment.

Key words: neonatal COVID-19, triage, vertical transmission, horizontal transmission, neonatal outcome.

\section{INTRODUCTION}

The coronavirus disease 2019 (COVID-19) as a global public health crisis is in the focus of numerous studies that have mainly evaluated the effects of COVID-19 on the general population, and there are insufficient data on its impact on vulnerable populations, such as neonates (1). By the end of the first pandemic year, it was estimated that about 300,000 neonates were born from pregnant women infected with the coronavirus, and millions of neonates were born into families that experienced stress due to the pandemic, even if they were not infected (2). Epidemiological data up to this point, have demonstrated that children, especially neonates, represent a minority of the overall cases, and data on the neonatal outcomes of pregnant women infected with the COVID-19 are limited $(3,4)$. New data accelerates health policy changes in pandemic-affected countries, continuously developing clinical management guidelines. The very rapid spread and increased mortality rate require exact information urgently, to identify and protect vulnerable popula- 
Table 1. Clinical, laboratory, and radiological findings in neonates with COVID-19

\begin{tabular}{|c|c|}
\hline \multicolumn{2}{|c|}{ Clinical manifestations in neonates with COVID-19 } \\
\hline Respiratory & Gastroenterological \\
\hline Moaning, groaning & abdominal distension \\
\hline fluttering of the nostrils & feeding problems \\
\hline tachypnea & vomiting \\
\hline chest retraction & diarrhea \\
\hline pallor, cyanosis & Neurological \\
\hline apnea & temperature instability \\
\hline cough & lethargy \\
\hline Laboratory findings & Radiological findings \\
\hline Leukocytes normal or decreased, lymphopenia & Infiltration on Chest X-rays \\
\hline Mild thrombocytopenia & \\
\hline Elevated Serum enzymes CK, ALP, ALT, AST, LDH & \\
\hline
\end{tabular}

tions, to prevent infection, reduce the need for intensive care, and reduce mortality rates (5).

From the beginning, neonatal units and patients had to be protected from all sources of new viral infection, which immediately complicated the organization and functioning of neonatal units, with the need for epidemiological screening, which requires double resources. Reliable and unmistakable triage is fundamental to this concept. Clinical manifestations, laboratory and radiological findings in neonates with COVID-19 are shown in the following table (Table 1) (2). However, all of these clinical, laboratory, and radiological findings are not specific and are not sufficient for COVID-19 neonates triage. Therefore, the only valid diagnosis is microbiological testing (2). Strong recommendations are to test neonates only if the results of the mother's tests are positive $(2,6)$. Finally, testing rules may vary for each facility, especially in hospital admission triage. The determinant is the local epidemiological situation and in accordance with the recommendations of the competent Department for Infection Prevention and Control.

Intra-hospital transfer of neonates should be limited with responsible risk management. Risk assessment is crucial in clinical decisions about the need for clinical intervention, diagnostic (radiological examinations, computed tomography, magnetic resonance imaging, eye examination, etc.) or therapeutic $(7,8)$. If possible, they should be postponed until the test arrives. However, if the clinical intervention cannot be delayed, neonates must be transported in a closed incubator and then managed according to current protocols. It is mandatory to follow the recommendations of the local department for infection prevention and control, in order to reduce the possibility of spreading the infection. Treatment management may involve proac- tive care, such as intubation using personal protective equipment $(5,8)$. Supportive care is currently the only known effective therapy for COVID-19. Advanced support may be indicated if a severe deterioration in respiratory function occurs. There is no evidence of routine use of antiviral drugs, steroids, or interferons in neonates $(9,10,11)$. If necessary, consultations with a pediatric infectiologist or with the department for infection prevention and control are desirable.

In conclusion, neonates differ from older children in their reactions to exposure to severe acute respiratory syndrome and COVID-19 infection. The previous data describing the appearance of COVID-19 in this group are rare, and the recommendations and guidelines from the authorities are variable. The aim of this study was to describe the incidence, characteristics, transmission, and outcomes of COVID-19 infection in neonates who were hospitalized in Tuzla Canton and to emphasize the importance of quality triage in the prevention and control of infection.

\section{MATERIAL AND METHODS}

\section{Patients and study design}

A retrospective cohort study, which included all consecutive neonates suspected of COVID-19 infection, and which required screening supervision in the triage department, from those who required hospital treatment, either in the Neonatal Intensive Care Unit (NICU) or in the Neonatology Department of the Pediatric Clinic, University Clinical Center Tuzla for 12 months. (January 1 to December 31, 2020). They were mostly neonates from COVID-19 suspected and covid-19 positive mothers, hospitalized immediately after birth, but also neonates readmitted (with mothers) after they had already been discharged and stayed 
at home for a period. The study was approved by the Ethics Committee of the Institution.

\section{Methods}

Clinical and demographic data were obtained from medical records and electronic databases of patients treated in NICU and Neonatology Department, which included gender, gestational age, birth weight, perinatal risk factors, clinical presentation, laboratory findings, applied therapy, and the outcome. During admission, COVID-19 history data for mothers and neonates were specifically analyzed. All these neonates were first admitted to the neonatal triage department, respecting all the strict rules and recommendations for the prevention and control of infection. After clinical observation, including necessary diagnostic and therapeutic interventions, and including the COVID-19 test (Polymerase chain reaction - PCR of the nasopharyngeal swab), neonates were then selected according to the results and definitions of COVID-19 infection in neonates. The categories of COVID-19 disease in neonates are Confirmed Case, Suspected Case, and Case Contact. A confirmed case is a neonate who has laboratory confirmation for COVID-19. A suspected case is a neonate who has the symptoms of viral infection, with included COVID-19 in differential diagnosis, while testing is in progress. Contact with the case is a neonate that is asymptomatic but has been exposed to a healthcare professional or family member who is a symptomatic or confirmed case of COVID-19.

\section{COVID-19 triage protocol}

The first patient with COVID-19 in Bosnia and Herzegovina was confirmed on March 5, 2020. and on March 11, 2020, the World Health Organization (WHO) declared a COVID-19 pandemic (2). In order to preserve the free status of the COVID-19 neonatology department, another neonatology department with an intensive care unit (the neonatal triage department) was formed in our clinic, to treat neonates suspected of COVID-19. The operating principles and work in the neonatal triage department were organized with the implementation of all recommendations of the Department of Prevention and Infection Control. The only valid diagnosis for COVID-19 is microbiological testing. Strong recommendations are to test neonates only if the results of the mother's tests are positive, but we tested all hospitalized neonates. Neonates, COVID-19 Confirmed Case, Suspected Case or Case Contact, were admitted to the isolation room, in consultation with the local Infection Prevention and Control Department. Appropriate precautions against infection were taken, and neonates were, as ideally recommended, kept in a closed incubator until test results arrived.

In treated neonates, clinical presentation, applied therapy, length of hospitalization, and the outcome were analyzed. From laboratory findings, we particularly analyzed potential markers of infection, including C-reactive protein (CRP), Complete blood cell (CBC) counts, the highest and lowest value for white blood cell (WBC) count, absolute neutrophil count (ANC), platelet count, and coagulation status.

\section{Statistical analysis}

For statistical analysis standard methods of descriptive statistics (central tendency measures, dispersion measures) were used. Parametric and non-parametric significance tests ( $\mathrm{X}^{2}$-test, respectively, Fisher's exact test and Student's t-test) were used to test the significance of differences between the samples. Statistical hypotheses were tested at a significance level of $\alpha=0.05$, i.e. The difference between the samples is considered significant if $p<0.05$. We used Systat Software, Systat Inc, Evanston, IL, USA for statistical processing of data.

\section{RESULTS}

In the period from January 1 to December 31 , 2020, 620 neonates were treated in the Pediatric Clinic of the University Clinical Center Tuzla, of which 370 in the Neonatology Department and 250 in the Neonatal Intensive Care Unit. This is slightly below the annual average from the experience of the previous five years but in line with the experiences of all departments and clinics in this year's COVID-19 environment.

In the observed period, in the neonatal triage department, 111 neonates suspected of COVID-19 were treated. Among them were 92 neonates of mothers suspected of COVID-19, and 19 neonates of mothers positive for COVID-19. Among 92 neonates of COVID-19 suspected mothers, 66 were admitted immediately after birth, while 26 were readmitted (with mothers) after they had already been discharged and stayed at home for a period. Among 19 neonates from COVID-19 positive mothers, 16 were admitted immediately after birth, while 3 were hospitalized as re-admission after discharge home after birth (Table 2).

Maternal perinatal data and COVID-19 history are shown in Table 3 . There was no statistically significant difference in maternal perinatal data in the two observed groups (COVID-19 suspected and COVID-19 positive mothers). Maternal perinatal data and COVID-19 history in our study were not significantly different nor spe- 
Table 2. COVID-19 status of neonates hospitalized in the triage unit

\begin{tabular}{|l|c|c|}
\hline \multirow{2}{*}{ Time of neonatal hospital admission } & \multicolumn{2}{|c|}{ Maternal COVID-19 status } \\
\cline { 2 - 3 } & $\begin{array}{c}\text { COVID-19 suspected } \\
\text { mother }\end{array}$ & $\begin{array}{c}\text { COVID-19 positive } \\
\text { mother* }\end{array}$ \\
\hline Immediately after birth & 66 & 16 \\
\hline COVID-19 neonatal status* & Negative 66 & 3 \\
\hline Readmission after discharge home & 26 & Positive 3 \\
\hline COVID-19 neonatal status & Negative 26 & 16 \\
\hline \multicolumn{2}{|c|}{$\mathrm{X}^{2}$-test $\mathrm{p}<0.001$; Yates corrected $\mathrm{X}^{2}$-test: $\mathrm{p}=0.0005$; Fisher's exact test: $\mathrm{p}=0.001$} \\
\hline \multicolumn{2}{|r}{$*$ COVID-19 status tested by PCR of nasopharyngeal swab } \\
\hline
\end{tabular}

Table 3. Maternal perinatal data and COVID-19 symptoms

\begin{tabular}{|l|c|c|c|}
\hline \multicolumn{3}{|c|}{ Maternal perinatal data of observing neonates } \\
\hline Maternal perinatal data & $\begin{array}{c}\text { COVID-19 } \\
\text { suspected mother } \\
(\mathrm{n}=66)\end{array}$ & $\begin{array}{c}\text { COVID-19 } \\
\text { positive mother } \\
(\mathrm{n}=16)\end{array}$ & $\mathrm{p}$ \\
\hline Primiparous, n (\%) & $34(51.5)$ & $8(0.5)$ & 0,9137 \\
\hline Multiparous, n (\%) & $32(48.5)$ & $8(0.5)$ & 0,9131 \\
\hline Vaginal delivery, n (\%) & $46(69.7)$ & $9(56.2)$ & 0,3048 \\
\hline Cesarean delivery, n (\%) & $20(30.3)$ & $7(43.7)$ & 0,3044 \\
\hline \multicolumn{2}{|c|}{ COVID-19 history and prepartum clinical presentation } \\
\hline Asymptomatic, n (\%) & $11(16.7)$ & $2(12.5)$ & 0,6827 \\
\hline Fever, n (\%) & $16(24.2)$ & $6(37.5)$ & 0,2828 \\
\hline Other mild symptoms, n (\%) & $39(59.1)$ & $8(0.5)$ & 0,5096 \\
\hline
\end{tabular}

Table 4. Neonatal-perinatal data and laboratory findings

\begin{tabular}{|c|c|c|c|}
\hline \multirow[t]{2}{*}{ Parameter } & $\begin{array}{l}\text { Neonates from } \\
\text { COVID-19 suspected } \\
\text { mothers }(\mathrm{n}=66)\end{array}$ & $\begin{array}{l}\text { Neonates from } \\
\text { COVID-19 positive } \\
\text { mothers }(\mathrm{n}=16)\end{array}$ & \multirow[t]{2}{*}{$\mathrm{p}$} \\
\hline & mean $\pm \mathrm{SD}$ & mean $\pm \mathrm{SD}$ & \\
\hline Gestational age (weeks) & $37.10 \pm 3.61$ & $39.00 \pm 1.68$ & 0.0457 \\
\hline Birth weight (grams) & $3042.76 \pm 903.09$ & $3503.53 \pm 470.79$ & 0.0457 \\
\hline AS in the 1st minute & $8.21 \pm 1.05$ & $8.53 \pm 0.87$ & 0.229 \\
\hline AS in the 5th minute & $8.55 \pm 0.63$ & $8.76 \pm 0.56$ & 0.2259 \\
\hline $\mathrm{CRP}(\mathrm{mg} / \mathrm{L})$ & $6.93 \pm 11.73$ & $7.16 \pm 13.96$ & 0.9461 \\
\hline Erythrocytes $\times 10^{12} / \mathrm{L}$ & $4.58 \pm 0.86$ & $4.67 \pm 0.89$ & 0.6796 \\
\hline Hemoglobin $(\mathrm{g} / \mathrm{L})$ & $165.51 \pm 34.34$ & $167.00 \pm 37.26$ & 0.8794 \\
\hline Hematocrit (proportion) & $0.46 \pm 0.09$ & $0.47 \pm 0.09$ & 0.6942 \\
\hline Platelets $\times 10^{9} / \mathrm{L}$ & $251.03 \pm 89.10$ & $279.82 \pm 53.95$ & 0.2207 \\
\hline Leukocytes $\times 10^{9} / \mathrm{L}$ & $14.66 \pm 7.36$ & $17.39 \pm 8.26$ & 0.1974 \\
\hline Neutrophil content (proportion) & $0.46 \pm 0.15$ & $0.48 \pm 0.17$ & 0.6588 \\
\hline $\mathrm{ANC} \times 10^{9} / \mathrm{L}$ & $6140.69 \pm 3698.5$ & $7469.41 \pm 4144.2$ & 0.2115 \\
\hline Lymphocyte content (proportion) & $0.37 \pm 0.15$ & $0.35 \pm 0.18$ & 0.6627 \\
\hline Intensive treatment (days) & $5.07 \pm 9.42$ & $0.82 \pm 2.32$ & 0.0742 \\
\hline
\end{tabular}


Table 5. Clinical presentation in the two observed groups of neonates

\begin{tabular}{|l|c|c|c|}
\hline \multicolumn{1}{|c|}{ Parameters n (\%) } & $\begin{array}{c}\text { Neonates from } \\
\text { COVID-19 } \\
\text { suspected mothers } \\
(\mathrm{n}=66)\end{array}$ & $\begin{array}{c}\text { Neonates from } \\
\text { COVID-19 } \\
\text { positive mothers } \\
(\mathrm{n}=16)\end{array}$ & $\mathrm{p}$ \\
\hline Respiratory distress syndrome & $11(16.7)$ & $2(12.5)$ & 0.6827 \\
\hline Pneumonia & $9(13.6)$ & $3(18.7)$ & 0.6031 \\
\hline Intracranial hemorrhage & $12(18.2)$ & $4(25)$ & 0.5368 \\
\hline Coagulation disorders & $18(27.3)$ & $2(12.5)$ & 0.2171 \\
\hline Confirmed microbial isolates & $9(13.4)$ & $4(25)$ & 0.2639 \\
\hline No antibiotic therapy & $7(10.6)$ & $7(43.7)$ & $\mathbf{0 . 0 0 1 6}$ \\
\hline First line of antibiotics & $13(19.7)$ & $9(56.2)$ & $\mathbf{0 . 0 0 3 1}$ \\
\hline Second line of antibiotics & $9(13.6)$ & 0 & 0.1176 \\
\hline Blood products & $13(19.7)$ & $2(12.5)$ & 0.5039 \\
\hline Phototherapy & $11(16.7)$ & $2(12.5)$ & 0.6827 \\
\hline Inotropes & $5(7.6)$ & 0 & 0.2561 \\
\hline Intravenous immunoglobulins & $7(10.6)$ & 0 & 0.1733 \\
\hline Mechanical ventilation & $6(9.1)$ & 0 & 0.2103 \\
\hline Exogenous surfactant & $5(7.6)$ & 0 & 0.2561 \\
\hline Umbilical venous catheter & $13(19,7)$ & $2(12.5)$ & 0.5039 \\
\hline Intensive Treatment (NICU) & $14(21.2)$ & 0.4303 \\
\hline & nICU) & \\
\hline
\end{tabular}

cific in their presentation. Cesarean delivery was a more common option in COVID-19 positive mothers but without statistical significance. As for COVID-19 history, fever was more commonly observed in COVID-19 positive mothers, compared to the group of COVID-19 suspected mothers, but this difference was not statistically significant. Related to COVID-19 symptomatology, mild to moderate symptoms dominated our study in mothers. There has not been a severe respiratory failure, need for ventilatory support for mothers, and maternal deaths due to COVID-19, until now.

Neonatal-perinatal data and laboratory findings are shown in Table 4. Clinical presentations in the two observed groups of neonates are shown in Table 5. If we analyze the data from neonates, treated immediately after birth, we conclude that the group of neonates from COVID-19 positive mothers was uniform, they were neonates with statistically better gestational age and birth weight, and these were neonates with better clinical status, and with significantly less required treatment options, compared to neonates from COVID-19 suspected mothers. All these neonates, finally, had a negative COVID-19 test and were recorded without significant laboratory and radiological deviations. After the observation in the triage department, all neonates continued their treatment in the Neonatology department with the promoted recommendations of the department for prevention and control of infection.
Results on neonatal COVID-19 status showed that all neonates hospitalized immediately after birth, from both COVID-19 suspect and COVID-19 positive mothers, were negative for COVID-19. In a group of neonates hospitalized as a re-admission after discharge home, 26 of them from COVID-19 suspected mothers, also were negative for COVID-19 (as well as their mothers finally). The only three COVID-19 positive neonates in our experience were precisely the neonates of the three positive mothers, admitted as re-admissions after previous discharge home, which showed statistically significant differences in horizontal transmission compared to vertical $\left(\mathrm{X}^{2}\right.$-test $\mathrm{p}<0.001$; Yates corrected $\mathrm{X}^{2}$-test: $\mathrm{p}=0.0005$; and Fisher's exact test: $\mathrm{p}=0.001)$. Three neonates with a positive COVID-19 test had mild symptoms of the disease, mostly one-day fever, and with isolation, monitoring, and symptomatic therapy, they all recovered completely. All of these neonates are under further follow-up after discharge from the hospital, and all are, for now, in good general condition, and all have continued to breastfeed.

\section{DISCUSSION}

Consistent with results and reports to date, children are not dominant among the diagnosed cases of COVID-19, and they usually count approximately 1\%$5 \%$ (1). In general, COVID-19 appears to be a less se- 
vere disease for children than for adults and almost 90\% of pediatric patients are diagnosed as an asymptomatic or mild disease (1). However, $5-10 \%$ of cases can be severe, usually in patients younger than 1 year of age and in patients who have severe comorbidity (11). Despite many published pediatric reports, epidemiological, clinical patterns of COVID-19 and treatment approaches in pediatric patients are still unclear. There is little data related to neonates. We follow them through studies of infected pregnant women $(12,13)$. COVID-19 during pregnancy may be associated with severe maternal morbidity and the impact on the outcome of pregnancy and neonates is not completely clear, especially if the infection occurs early in pregnancy $(3,4)$. Because it is known how harmful viral infections can be during pregnancy, and that they can affect the fetus in several ways: from direct transmission through the placenta to inflammatory responses that can disrupt metabolism in the uterus and can negatively affect fetal growth (4). Some indications increased rates of preterm birth may be associated with maternal COVID-19 infections, and some studies suggest that severe disease in early pregnancy may be associated with a higher risk of stillbirths $(12,14)$.

Data for 2020 for our institution also suggest a slight increase in the prematurity rate, although there is a slight decrease in the total number of live births. We can only theoretically link this observation to this year's pandemic, and we cannot scientifically substantiate it because we did not conduct mass and repeated tests, so there was no permanent screening for COVID-19 in pregnant women throughout pregnancy. For now, it is considered that there is no strong evidence of vertical transmission of the infection from pregnant women to neonates, also, at this time, there are no reports of an increased risk of congenital anomalies in children born to COVID-19 positive pregnant women $(6,7,12)$. According to the published case reports, it appears that the COVID-19 virus has a very low rate of infection among neonates, which is estimated at $1-5 \%$ worldwide $(13$, $14,15)$. Most cases are considered to be the result of horizontal transmission from the environment, in the household by droplets from another family member, and therefore potentially possible from health professionals, as a potential healthcare-related infection $(15,16)$.

In our study among 111 neonates suspected of COVID-19, all neonates hospitalized immediately after birth, from both COVID-19 suspect and COVID-19 positive mothers, were negative for COVID-19, which is consistent with reports that there is no vertical transmission COVID-19 from mothers to neonates $(4,6,7,15)$. In a group of neonates hospitalized as readmission after discharge home, 26 of them from COVID-19 suspected mothers, also were negative for COVID-19 (as well as their mothers finally). The only three COVID-19 positive neonates in our experience were precisely the neonates of the three positive mothers, admitted as readmissions after previous discharge home, which is also consistent with the published experiences of others, that neonates are mostly infected by horizontal transmission from the environment and COVID-19 positive family members $(15,16)$.

Maternal perinatal data and COVID-19 history in our study were not significantly different nor specific in their presentation. Cesarean delivery in our study was a more common option in COVID-19 positive mothers, who mainly showed mild to moderate symptoms. There was no severe respiratory failure, no need for ventilatory support for mothers, and no maternal deaths due to COVID-19, until now. Smith et all (3) in their study conclude that COVID-19 positive pregnant women present with fewer symptoms than the general population, while the results of Juan et all (9) suggest that COVID-19 in pregnant women may increase the risk of maternal mortality. We can conclude that, despite the growing number of published studies, there is still not enough valid data on the severity and complications of COVID-19 in pregnant women.

According to published reports, especially those from the beginning of the pandemic, guidelines for the management of neonates born to mothers with COVID-19, confirmed or suspected infection, vary from country to country, and routine separation of mothers and neonates after birth has been recommended in many countries $(16,17)$. Our research supports international guidelines, suggesting avoiding the separation of mother and child after birth, in case of suspected or confirmed COVID-19 infection in mothers (16).

According to the clinical presentation, neonates from the mothers suspected of COVID-19, in our study, were a heterogeneous group, with different, but still common perinatal symptoms and problems. It is noticeable that neonates from COVID-19 positive mothers, hospitalized immediately after birth, were a uniform group of term neonates with appropriate birth weight and with a better general condition, and less need for any intervention and treatment. Almost all similar studies find that there is no evidence for vertical transmission. According to Golden et al (4), a possible explanation would be that immune cells in the placenta also have antiviral capacity. Even studies that report more serious clinical presentation in early-infected neonates suggest that in some cases it might have been related to other neonatal conditions, such as preterm birth. Therefore, the longterm effects of early exposure COVID-19 are still unknown, although the short-term outcomes are excellent in these studies (16). After the observation in the triage department, all neonates continued their treatment in the Neonatology department with the promoted recommendations of the department for prevention and control of 
infection. Three neonates with a positive COVID-19 test had mild symptoms of the disease, mostly one-day fever, and with isolation, monitoring, and symptomatic therapy, they all recovered completely. Although COVID-19 is a new infectious disease, with still insufficiently known clinical manifestations in neonates, current findings suggest that in addition to having a lower incidence, they have mostly mild forms of the disease $(11,13,18)$. This is in line with published results, that hyperthermia, signs of upper respiratory tract infection, and poor feeding were more commonly reported in neonates diagnosed with COVID-19 later than 7 days after birth $(11,16)$. In our study, all of these neonates are under further follow-up after discharge from the hospital, and all are, for now, in good general condition, and all have continued to breastfeed. This differs from some previously published studies that have observed laboratory deviations, and the most common biochemical and haematological abnormalities were raised lactate, raised C-reactive proteins and a low lymphocyte count, and some report chest $\mathrm{x}$-ray abnormal findings, with ground-glass changes $(11,13,16)$.

Neonates, in addition to treatment, require social contact with the mother and family members for their growth and development. It is very important, if possible, to practice skin-to-skin contact between mother and child, as the results of recent studies are encouraging $(8,16)$. Concerning nutrition, breastfeeding remains the best source of nutrition for most neonates. To date, there is no evidence of the presence of COVID-19 in breast milk. Therefore, on June 23, 2020, the World Health Organization (WHO) issued recommendations regarding breastfeeding and COVID-19. COVID-19 positive mothers are encouraged to breastfeed their children while wearing a mask and practicing all hygiene rules (2). Due to the current COVID-19 pandemic, the supply of donor milk is limited (16). Some studies report suspected nosocomial transmission of COVID-19 to neonates, within neonatal units, suggesting that such units should be reevaluated in procedures to isolate highly infectious cases (8). Further research is needed to understand the real effects of limiting hospital visits on the spread of this highly transmissible virus.

Family engagement and presence depend on current location-specific guidelines for visitors. The assessment should be done in collaboration with the Infection Prevention and Control Department. The family will need support, depending on the outcome and especially in less fortunate circumstances. Available support services should be made available as soon as possible. Memories of neonates should be provided to the family, if possible, such as photographs, or the use of other virtual connections between mother, family, and neonates should be considered.
When considering discharge from the hospital, continued isolation should be provided if the neonates are discharged before the end of the isolation period. If the neonates' tests are positive, then isolation is recommended for at least 10 days after the onset of symptoms; or, until the fever ceases without the use of antipyretic drugs or until symptoms improve (respiratory, gastrointestinal, and systemic). It is reasonable to postpone audiological and other examinations while neonates are under protective supervision. It should be ensured that the confirmed status of COVID-19 mothers and neonates has previously been explained and forwarded to the competent health service.

\section{CONCLUSION}

In conclusion, neonates born to mothers with positive COVID-19 infection generally have favorable outcomes, with no convincing case of vertical transmission. In our study, the proportion of neonates with the disease is extremely low. Moreover, neonatal COVID-19 appears to be acquired postnatally and associated with favorable respiratory outcomes. For those reasons, the provision of respiratory care in neonates should continue in accordance with current standards. However, to protect and to stop any spread of COVID-19 infection, it is critical to emphasize the importance of quality triage for the prevention and control of infection, consistently implement safe practices including proper patient isolation and appropriate protective equipment. Finally, information is rapidly changing, and clinicians should often look out for new updates as the state of our knowledge evolves.

Conflict of Interests: The authors declare that there are no conflicts of interest related to this article.

Funding: None

\section{Licensing}

This work is licensed under a Creative Commons Attribution 4.0 International (CC BY 4.0) License. 


\title{
Sažetak
}

\section{KOVID-19 TRIJAŽA HOSPITALIZOVANIH NEONATUSA U TUZLANSKOM KANTONU}

\author{
Devleta Hadzic, ${ }^{1}$ Fahrija Skokic, ${ }^{1}$ Selmira Brkic ${ }^{2}$ \\ ${ }^{1}$ Pediatric Clinic, University Clinical Center of Tuzla, Bosnia and Herzegovina \\ ${ }^{2}$ Faculty of Medicine University of Tuzla, Bosnia and Herzegovina
}

Cilj studije: da se proceni incidencija, karakteristike, prenos i ishodi infekcije COVID-19 kod hospitalizovanih novorođenčadi u Tuzlanskom kantonu i naglasi važnost kvalitetne trijaže u prevenciji i kontroli infekcije.

Metode: Retrospektivna kohortna studija koja je obuhvatila svu uzastopnu novorođenčad suspektnu na infekciju COVID-19 koja su zahtevala nadzor i skrining na odeljenju trijaže, među onim koji su zahtevali hospitalizaciju u Klinici za dečije bolesti Univerzitetskog kliničkog centra Tuzla, tokom 12 meseci. (od 1. januara do 31. decembra 2020. godine). U statističkoj analizi primenjene su standardne metode, a istraživanje je odobrio Etički komitet institucije.

Rezultati: U posmatranom periodu, na odeljenju za trijažu lečeno je 111 novorođenčadi pod sumnjom na COVID-19, bez razlike u polnoj zastupljenosti. Među njima je bilo 92 novorođenčadi od majki suspektnih na COVID-19 (66 primljenih odmah nakon rođenja, 26 ponovo primljenih nakon prethodnog otpusta kući) i 19 novorođenčadi od majki pozitivnih na COVID-19 (16 primljenih neposredno nakon rođenja, 3 ponovni prijem). Kod majki pozitivnih na COVID-19, carski rez bio je češća opcija porođaja, a febrilnost češće primećeni simptom, ali bez statističke značajnosti.

Ključne reči: neonatalna COVID-19, trijaža, vertikalna transmisija, horizontalna transmisija, neonatalni ishod.

\section{REFERENCES}

1. Tezer H, Bedir Demirdağ T. Novel coronavirus disease (COVID-19) in children. Turk J Med Sci. 2020; 50(SI-1): 592603. doi: 10.3906/sag-2004-174.

2. World Health Organisation: WHO, www.who.int

3. Smith V, Seo D, Warty R, Payne O, Salih M, Chin $\mathrm{KL}$, et al. Maternal and neonatal outcomes associated with COVID-19 infection: a systematic review. PLoS One. 2020; 15(6): e0234187. doi: 10.1371/journal.pone.0234187.

4. Golden TN, Simmons RA. Maternal and neonatal response to COVID-19. Am J Physiol Endocrinol Metab. 2020; 319(2): E315-9. doi: 10.1152/ajpendo.00287.2020.
Novorođenčad od majki suspektnih na COVID-19 su činila heterogenu grupu, sa uobičajenim perinatalnim problemima, dok su novorođenčad od pozitivnih majki, hospitalizovana odmah po rođenju, gotovo svi bili terminska novorođenčad sa odgovarajućom porođajnom težinom, bez potrebe za značajnim lečenjem. Sva novorođenčad hospitalizovana odmah nakon rođenja bila su negativna na COVID-19. Jedino troje novorođenčadi pozitivnih na COVID-19 bilo je hospitalizovano nakon izvesnog boravka kod kuće, svi su imali blage simptome, uglavnom jednodnevnu temperature i svi su se potpuno oporavili. Sva ova novorođenčad nakon hospitalizacije su na daljem praćenju i za sada su dobrog opšteg stanja i svi su na prirodnoj ishrani.

Zaključak: Novorođenčad rođena od majki sa potvrđenom infekcijom COVID-19 uglavnom ima povoljne ishode, bez ubedljivog dokaza vertikalnog prenosa. COVID-19 u novorođenčadi je uglavnom stečena postnatalno i povezana sa povoljnim ishodima. Značaj kvalitetne trijaže u prevenciji i kontroli infekcije je presudan, uz doslednu primenu bezbednih praksi, uključujući odgovarajuću izolaciju pacijenta i odgovarajuću zaštitnu opremu.

5. Halliday HL, Speer CP. COVID-19 and neonatal resuscitation. Neonatology. 2020; 117(2): 132. doi: 10.1159/ 000508003.

6. Shalish W, Lakshminrusimha S, Manzoni P, Keszler M, Sant'Anna GM. COVID-19 and neonatal respiratory care: current evidence and practical approach. Am J Perinatol. 2020; 37(8): 780-91. doi: 10.1055/s-0040-1710522.

7. Griffin I, Benarba F, Peters C, Oyelese Y, Murphy T, Contreras D, et al. The Impact of COVID-19 Infection on labor and delivery, newborn nursery, and neonatal intensive care unit: prospective observational data from a single hospital system. Am J Perinatol. 2020; 37(10): 1022-30. doi: 10.1055/s-0040-1713416.

8. Chandrasekharan P, Vento M, Trevisanuto D, Partridge E, Underwood MA, Wiedeman J, et al. Neonatal resuscitation and postresuscitation care of infants born to mothers with suspected or confirmed SARS-CoV-2 Infection. Am J Perinatol. 2020; 37(8): 813-24. doi: 10.1055/s-0040-1709688.

9. Juan J, Gil MM, Rong Z, Zhang Y, Yang H, Poon LC. Effect of coronavirus disease 2019 (COVID-19) on maternal, perinatal and neonatal outcome: systematic review. Ultrasound Obstet Gynecol. 2020; 56(1): 15-27. doi: 10.1002/uog.22088. 
10. Zaigham M, Andersson O. Maternal and perinatal outcomes with COVID-19: A systematic review of 108 pregnancies. Acta Obstet Gynecol Scand. 2020; 99(7): 823-9. doi: 10.1111/aogs.13867.

11. Sankar J, Dhochak N, Kabra SK, Lodha R. COVID-19 in children: Clinical approach and management. Indian J Pediatr 2020; 87(6): 433-42. doi: 10.1007/s12098-020-03292-1.

12. Karimi-Zarchi M, Neamatzadeh H, Dastgheib SA, Abbasi H, Mirjalili SR, Behforouz A, et al. Vertical transmission of coronavirus disease 19 (COVID-19) from infected pregnant mothers to neonates: a review. Fetal Pediatr Pathol. 2020; 39(3): 246-50. doi: 10.1080/15513815.2020.1747120.

13. de Rose DU, Piersigilli F, Ronchetti MP, Santisi A, Bersani I, Dotta A, et al. Novel Coronavirus disease (COVID-19) in newborns and infants: What we know so far. Ital J Pediatr. 2020; 46(1): 56. doi:10.1186/s13052-020-0820-x.

14. Jain P, Thakur A, Kler N, Garg P. Manifestations in neonates born to COVID-19 positive mothers. Indian J Pediatr. 2020; 87(8): 644. doi: 10.1007/s12098-020-03369-x.

\section{Correspondence to/Autor za korespondenciju}

Devleta Hadžić

Univerzitetski klinički centar Tuzla, Klinika za dječije bolesti

Prof. dr. Ibre Pašić bb

75000 Tuzla, Bosna i Hercegovina

0038735303733

e-mail: devletahadzic@yahoo.com
15. Zimmermann $\mathrm{P}$, Curtis N. Coronavirus infections in children including COVID-19: An overview of the epidemiology, clinical features, diagnosis, treatment and prevention options in children. Pediatr Infect Dis J. 2020; 39(5): 355-68. doi: 10.1097/inf.0000000000002660.

16. Gale C, Quigley MA, Placzek A, Knight M, Ladhani $\mathrm{S}$, Draper ES, et al. Characteristics and outcomes of neonatal SARS-CoV-2 infection in the UK: a prospective national cohort study using active surveillance. Lancet Child Adolesc Health. 2021; 5(2): 113-21. doi: 10.1016/S2352-4642(20)30342-4.

17. Yeo KT, Oei JL, De Luca D, Schmolzer GM, Guaran $\mathrm{R}$, Palasanthiran $\mathrm{P}$ et al. Review of guidelines and recommendations from 17 countries highlights the challenges that clinicians face caring for neonates born to mothers with COVID-19. Acta Paediatr. 2020; 109(11): 2192-207. doi: 10.1111/apa.15495.

18. Sporisevic L, Mesihović-Dinarevic S, Joguncic A, Pilav A. Coronavirus disease 2019 (COVID-19): a new pediatric challenge. JHSCI. 2020; 10(2): 103-8. doi: 10.17532/jhsci.2020.9720. 